\title{
Teaching NeuroImages: Linear Radial Periventricular Enhancement in Glial Fibrillary Acidic Protein Astrocytopathy
} Yongyao Kong, MD, Andrew McKeon, MD, Odelia S.Q. Koh, MD, Yi Rong Chiew, MD, Bela Purohit, MD,
Chee Fang Chin, MD, Anastasia Zekeridou, MD, PhD, and Adeline S.L. Ng, MD

Neurology ${ }^{\circledR}$ 2021;96:e2454-e2455. doi:10.1212/WNL.0000000000011496

Figure Baseline and Interval MRI Features in Glial Fibrillary Acidic Protein Astrocytopathy After Immunosuppressive Treatment

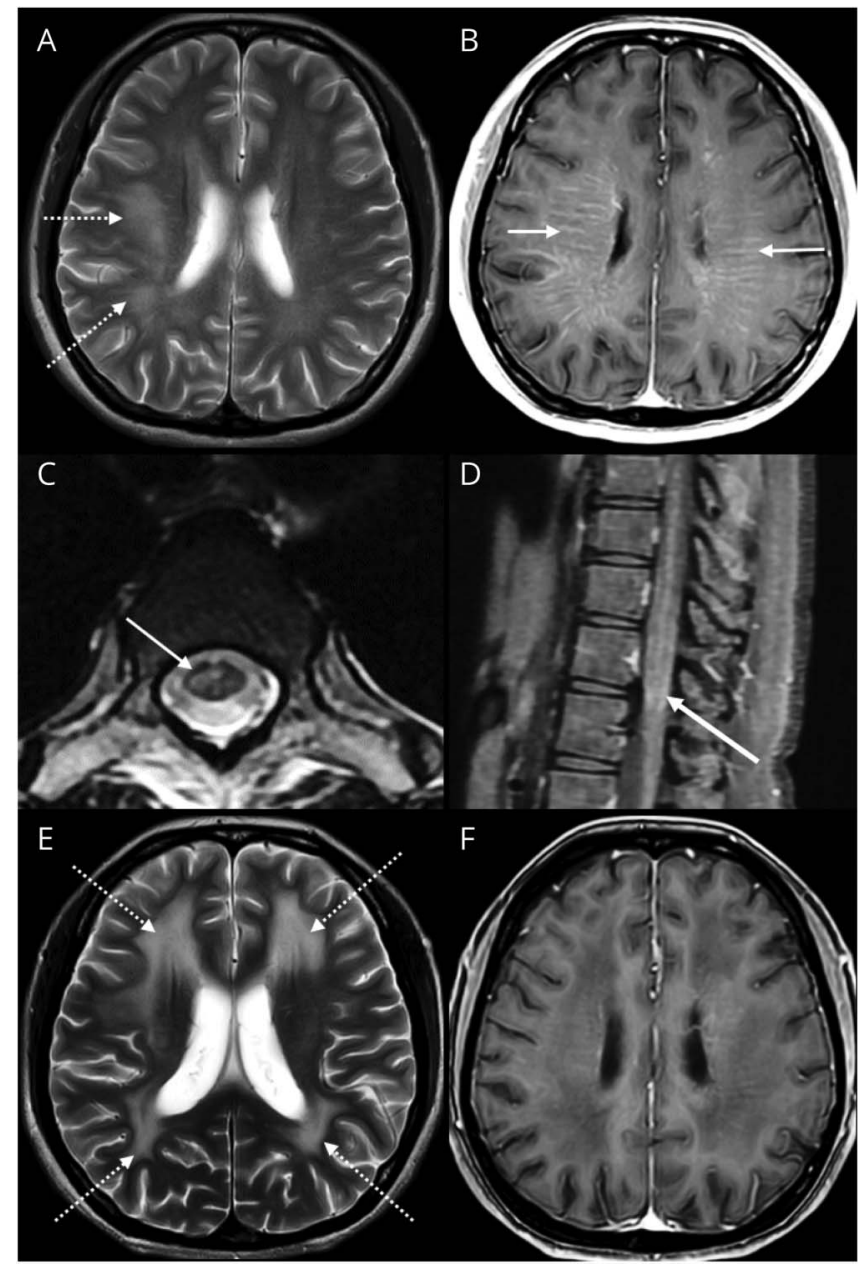

(A) Baseline T2-weighted deep white matter hyperintensities. (B) Baseline contrast-enhanced T1weighted linear/radial perivascular enhancement. (C) Baseline T2weighted dorsal cord focal hyperintensity. (D) Contrast-enhanced T1-weighted leptomeningeal enhancement over conus. (E) Interval T2-weighted progression/confluence of hyperintensities in periventricular and deep white matter with background involution. (F) Corresponding resolution of radial perivascular enhancement.
A 48-year-old woman presented with asymptomatic painless optic disc swelling, seizures, cognitive decline, and weakness over 3 months. She had an upper motor neuron pattern of grade $4 / 5$ weakness in all 4 limbs. Brain MRI revealed striking linear radial perivascular enhancement in the deep white matter ${ }^{1,2}$ (figure, A and B); MRI spine revealed longitudinally extensive $\mathrm{C} 3$-to-conus cord $\mathrm{T} 2$ hyperintensity and $\mathrm{T} 1$ enhancement $^{2}$ (figure, $\mathrm{C}$ and $\mathrm{D}$ ). CSF
Correspondence

Dr. Ng

adeline.ng.s.l@

singhealth.com.sg

\section{MORE ONLINE}

$\rightarrow$ Teaching slides

links.lww.com/WNL/ B306

From the Departments of Neurology (Y.K., O.S.Q.K., Y.R.C., A.S.L.N.) and Neuroradiology (B.P.), National Neuroscience Institute, Singapore; Departments of Laboratory Medicine and Pathology and Neurology (A.M., A.Z.), Mayo Clinic College of Medicine, Rochester, MN; National Healthcare Group Eye Institute (C.F.C.), Tan Tock Seng Hospital; and Neuroscience and Behavioural Disorders (A.S.L.N.), Duke-NUS Medical School, Singapore.

Go to Neurology.org/N for full disclosures. Funding information and disclosures deemed relevant by the authors, if any, are provided at the end of the article. 
demonstrated glial fibrillary acidic protein (GFAP) pattern by indirect immunofluorescence with GFAP $\alpha$ specificity confirmed by cell-based assay. The patient improved clinically (figure, E and F) with steroid treatment. Linear/radial perivascular enhancement in the deep white matter prompts consideration of a corticosteroid-responsive meningoencephalomyelitis termed autoimmune GFAP astrocytopathy. ${ }^{1}$

\section{Study Funding}

No targeted funding reported.

\section{Disclosure}

A. McKeon serves as an editorial board member of Neuro$\log y^{\circledR}$ : Neuroimmunology and Neuroinflammation; received research support from Medimmune, Euroimmun, Grifols, and Alexion; and has patents pending for Septin 5, GFAP, PDE10A, Kelch-11, and MAP1B as markers of neurologic autoimmunity and paraneoplastic disorders. A. Zekeridou has a patent pending for PDE10A-IgG paraneoplastic autoimmunity. Y. Kong, O.S.Q. Koh, Y.R. Chiew, B. Purohit, C.F. Chin, and A.S.L. Ng report no disclosures. Go to Neurology. org $/ \mathrm{N}$ for full disclosures.

Appendix Authors

\begin{tabular}{lll}
\hline Name & Location & Contribution \\
\hline $\begin{array}{ll}\text { Yongyao } \\
\text { Kong, MD }\end{array}$ & $\begin{array}{l}\text { Department of Neurology, } \\
\text { National Neuroscience Institute, } \\
\text { Singapore }\end{array}$ & $\begin{array}{l}\text { Writing of } \\
\text { manuscript }\end{array}$ \\
\hline
\end{tabular}

Appendix (continued)

\begin{tabular}{|c|c|c|}
\hline Name & Location & Contribution \\
\hline $\begin{array}{l}\text { Andrew } \\
\text { McKeon, MD }\end{array}$ & $\begin{array}{l}\text { Departments of Laboratory } \\
\text { Medicine and Pathology and } \\
\text { Neurology, Mayo Clinic College of } \\
\text { Medicine, Rochester, MN }\end{array}$ & $\begin{array}{l}\text { Writing of } \\
\text { manuscript }\end{array}$ \\
\hline $\begin{array}{l}\text { Odelia S.Q. } \\
\text { Koh, MD }\end{array}$ & $\begin{array}{l}\text { Department of Neurology, } \\
\text { National Neuroscience Institute, } \\
\text { Singapore }\end{array}$ & Acquisition of data \\
\hline $\begin{array}{l}\text { Yi Rong } \\
\text { Chiew, MD }\end{array}$ & $\begin{array}{l}\text { Department of Neurology, } \\
\text { National Neuroscience Institute, } \\
\text { Singapore }\end{array}$ & Acquisition of data \\
\hline $\begin{array}{l}\text { Bela Purohit, } \\
\text { MD }\end{array}$ & $\begin{array}{l}\text { Department of Neuroradiology, } \\
\text { National Neuroscience Institute, } \\
\text { Singapore }\end{array}$ & Acquisition of data \\
\hline $\begin{array}{l}\text { Chee Fang } \\
\text { Chin, MD }\end{array}$ & $\begin{array}{l}\text { National Healthcare Group Eye } \\
\text { Institute, Tan Tock Seng Hospital, } \\
\text { Singapore }\end{array}$ & Acquisition of data \\
\hline $\begin{array}{l}\text { Anastasia } \\
\text { Zekeridou, } \\
\text { MD, PhD }\end{array}$ & $\begin{array}{l}\text { Departments of Laboratory } \\
\text { Medicine and Pathology and } \\
\text { Neurology, Mayo Clinic College of } \\
\text { Medicine, Rochester, MN }\end{array}$ & $\begin{array}{l}\text { Writing of } \\
\text { manuscript }\end{array}$ \\
\hline $\begin{array}{l}\text { Adeline S.L. } \\
\text { Ng, MD }\end{array}$ & $\begin{array}{l}\text { Department of Neurology, } \\
\text { National Neuroscience Institute, } \\
\text { Singapore }\end{array}$ & $\begin{array}{l}\text { Revision of } \\
\text { manuscript for } \\
\text { intellectual content }\end{array}$ \\
\hline
\end{tabular}

\section{References}

1. Fang B, McKeon A, Hinson SR, et al. Autoimmune glial fibrillary acidic protein astrocytopathy: a novel meningoencephalomyelitis. JAMA Neurol 2016;73: 1297-1307.

2. Flanagan EP, Hinson SR, Lennon VA, et al. Glial fibrillary acidic protein immunoglobulin $\mathrm{G}$ as biomarker of autoimmune astrocytopathy: analysis of 102 patients. Ann Neurol 2017;81:298-309. 


\section{Neurology}

\section{Teaching NeuroImages: Linear Radial Periventricular Enhancement in Glial Fibrillary Acidic Protein Astrocytopathy}

Yongyao Kong, Andrew McKeon, Odelia S.Q. Koh, et al.

Neurology 2021;96;e2454-e2455 Published Online before print January 6, 2021

DOI 10.1212/WNL.0000000000011496

\section{This information is current as of January 6,2021}

Updated Information \&

Services

References

Subspecialty Collections

Permissions \& Licensing

Reprints including high resolution figures, can be found at: http://n.neurology.org/content/96/19/e2454.full

This article cites 2 articles, 0 of which you can access for free at: http://n.neurology.org/content/96/19/e2454.full\#ref-list-1

This article, along with others on similar topics, appears in the following collection(s):

All Spinal Cord

http://n.neurology.org/cgi/collection/all_spinal_cord Autoimmune diseases

http://n.neurology.org/cgi/collection/autoimmune_diseases MRI

http://n.neurology.org/cgi/collection/mri

Information about reproducing this article in parts (figures,tables) or in its entirety can be found online at:

http://www.neurology.org/about/about_the_journal\#permissions

Information about ordering reprints can be found online:

http://n.neurology.org/subscribers/advertise

Neurology ${ }^{\circledR}$ is the official journal of the American Academy of Neurology. Published continuously since 1951, it is now a weekly with 48 issues per year. Copyright (? 2021 American Academy of Neurology. All rights reserved. Print ISSN: 0028-3878. Online ISSN: 1526-632X.

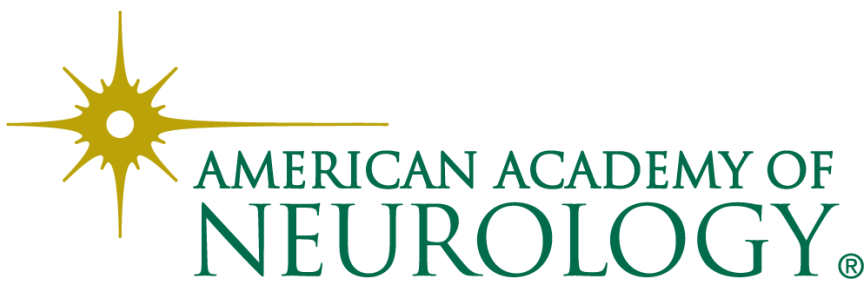

